[Agr. Biol. Chem., Vol. 36, No. 10, p. 1701 1706, 1972]

\title{
Some Problems Involved in Ampicillin Formation by Kluyvera's Penicillin Acylase ${ }^{\dagger}$
}

\author{
By Seigo Takasawa, Ryo OKachi, Isao Kawamoto, \\ Mitsuyoshi Yamamoto and Takashi NarA \\ Tokyo Research Laboratory, Kyowa Hakko Kogyo Co., Ltd. \\ Asahimachi, Machidashi, Tokyo \\ Received January 31, 1972
}

\begin{abstract}
The cell growth of Kluyvera citrophila KY3641, capable of producing $\alpha$-aminobenzylpenicillin (APc) from 6-aminopenicillanic acid (6-APA) and phenylglycine, was stimulated by glutamic acid, serine or proline, or by $\mathrm{pH}$ control with tartaric acid or fumaric acid.

Penicillinase produced in an early stage of growth or $\mathrm{pH}$-controlled culture was inactivated by alkaline treatment (incubation of cells at $40^{\circ} \mathrm{C}$ for 5 to $24 \mathrm{hr}$ in $\mathrm{pH} 7.5$ to 9.5 ) without inactivation of penicillin acylase. Surface active agents enhanced APc production. On the other hand, phenylalanine and some inorganic compounds inhibited this production.

This bacterium formed APc from penicillin G, but amounts of APc formed were only $9 \mu \mathrm{g}$ from $20 \mathrm{mg}$ of penicillin $\mathrm{G}$.
\end{abstract}

It was previously reported that the intact cells of Kluyvera citrophila KY3641 decomposed penicillin $G$ to form 6-aminopenicillanic acid (6-APA) in alkaline side ${ }^{1,2)}$ and formed $\alpha$-aminobenzylpenicillin (APc) from 6-APA and phenylglycine derivatives in acidic side..$^{3,4)}$

During the investigation of APc production, some problems arose: (1) the growth of $K$. citrophila was very poor, (2) this strain contained penicillinase like enzyme which decomposed penicillin $G$ to form penicilloic acid in the early stage of growth (3) how the productivity of APc is raised and (4) whether APc can formed directly from penicillin $G$. In this paper, some results pertaining to those problems are reported.

+ Enzymatic Synthesis of $D[-]-\alpha$-Aminobenzylpenicillin [Part 4] (see reference ${ }^{1,2,4)}$ )

A part of this work was presented at the Annual Meeting of Japanese Agricultural Chemical Society in Tokyo, April, 1971.

Abbreviation: APc; $\mathrm{D}[-]-\alpha-$ Aminobenzylpenicillin (Ampicillin), 6-APA; 6-Aminopenicillanic acid, DCW; Dry cell weight.

\section{METHODS}

Strain and culture condition. Kluyvera citrophila (KY3641) was employed. This strain was cultured with shaking at $30^{\circ} \mathrm{C}$ for 1 to 3 days in the following medium, polypeptone $1 \%$, yeast extract $1 \%$ and $\mathrm{NaCl}$ $0.25 \%$ at pH 7.0 . In some experiments, some materials were added to this medium as described in each experiment. For the 5 liter-jar fermentation, the strain was cultured under the following conditions, temperature $30^{\circ} \mathrm{C}$, aeration $5 \mathrm{liter} / \mathrm{min}$ and agitation, $350 \mathrm{rpm}$.

Conditions of $A P C$ formation. Reaction mixture used was: 6-APA $10 \mathrm{mg}$, DL-phenylglycine methylester $25 \mathrm{mg}$ and cells $30 \mathrm{mg}$ in $1.0 \mathrm{ml}$ of $\mathrm{M} / 30$ phosphate buffer at $\mathrm{pH}$ 6.5. In some experiments, components of the reaction mixture and $\mathrm{pH}$ were changed as described in each experiment. Cells were prepared as following: cells were collected by centrifugation $(3000 \mathrm{rpm})$ from culture broth and washed twice with water by centrifugation. The reaction was run at $35^{\circ} \mathrm{C}$ for $24 \mathrm{hr}$. The reaction was stopped by the removal of the cells from the reaction mixture with centrifugation.

Assay method. Assay methods were described in previous papers. ${ }^{1,2,4)}$ Cell growth was determined as DCW by the turbidity of broth at $660 \mathrm{~m} \mu$. APc 
formed was determined both by the cylinder plate method using $E$. coli as a test organism and by silicagel TLC by use of a solvent system consisting of $n$-butylacetate- $n$-butanol-acetic acid-water $(80: 15: 40: 24)$. APc was detected both by the bioautography using $E$. coli and by the colored reaction ${ }^{11}$ with starch$0.01 \mathrm{M}$ iodine. In this solvent system, the following $R f$ values were obtained, penicillin $\mathrm{G}, 0.8$, penicilloic acid 0.5, APc 0.4 and 6-APA 0.2.

\section{RESULTS AND DISCUSSION}

Effects of amino acids, organic acids and sugars on the growth of $K$. citrophila

The growth level of $K$. citrophila was only $3 \sim 4 \mathrm{mg} / \mathrm{ml}$ as DCW in the medium described in Methods. Effects of amino acids, organic acids and sugars on the growth were therefore tested to stimulate it. In this experiment, $0.5 \%$ of each compound was added to the basal medium and $K$. citrophila was grown at $30^{\circ} \mathrm{C}$ for $24 \mathrm{hr}$. As shown in Table I, glutamic acid, serine and proline increased

Table 1. EFfects of Additions on Cell Growth ANd Ampicillin Formation

$K$. citrophila was cultured in the basal medium containing $0.5 \%$ of additions at $30^{\circ} \mathrm{C}$ for $24 \mathrm{hr}$.

\begin{tabular}{lcc}
\multicolumn{1}{c}{ Additions } & Cell growth & $\begin{array}{c}\text { Formation of } \\
\text { APc }\end{array}$ \\
\hline Sucrose & + & \pm \\
Glucose & - & - \\
Na-Fumarate & + & + \\
Na-Tartarate & + & + \\
Na-Lactate & + & \pm \\
Na-Succinate & + & \pm \\
Na-Glutamate & + & \pm \\
Na-Aspartate & + & \pm \\
Asparagine & + & + \\
Serine & + & + \\
Proline & + & + \\
Methionine & \pm & + \\
\hline$-<90 \%$ of control (no additon) & $\pm 0 \sim 110 \%$ of \\
control $+110 \sim 130 \%$ of control $+130 \sim 150 \%$ of \\
control
\end{tabular}

the growth up to $130 \sim 150 \%$ and organic acids, aspartic acid and asparagine increased to $110 \sim 130 \%$ but glucose did not support the cell growth.

On the other hand, penicillin acylase activity was not enhanced by these materials, whereas tartaric acid, fumaric acid, asparagine, serine and methionine promoted the enzyme activity slightly. Other sugars (glycerol, mannitol, sorbitol, fructose, lactose and maltose), amino acids (lysine, alanine, glycine, phenylalanine, glutamine, threonine, tyrosine, tryptophan, histidine, arginine, cystine and homoserine) and organic acids (Na-citrate, Na-maleite and Na-gluconate) did not show any significant effect on the growth and enzyme activity, whereas fructose, lactose, maltose, Na-maleite, Na-gluconate, alanine, glycine, tyrosine, tryptophan, cystine and homoserine inhibited the cell growth.

\section{Effect of $p H$ control on the growth and penicillin acylase}

Previous experiment showed that organic acids promoted the cell growth. Effects of pH control with organic acids were hence examined. $\mathrm{pH}$ of cultures was controlled at 7.5 with $1 \mathrm{M}$ organic acids. As shown in Fig. 1, the growth was $6 \mathrm{mg} / \mathrm{ml}$ on the culture

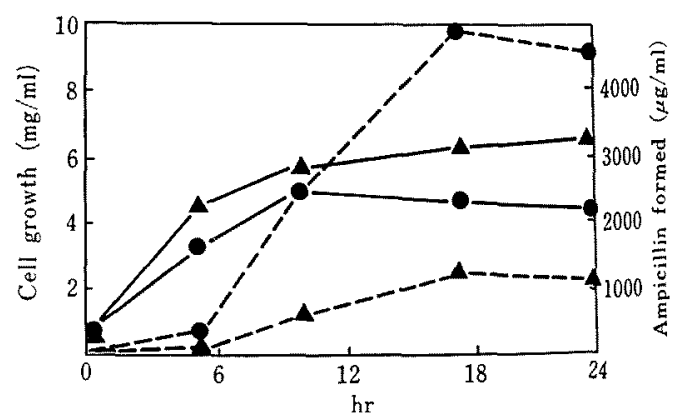

FiG. 1. Effect of pH Control on Cell Growth and Ampicillin Formation.

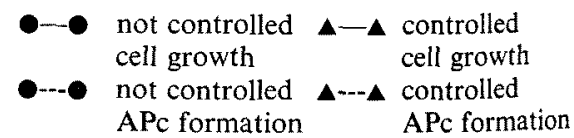

The basal medium was used. $\mathrm{pH}$ was controlled to 7.5 with $1 \mathrm{M}$ of tartaric acid. 
medium whose $\mathrm{pH}$ was controlled with tartaric acid during the growth, but the growth on the uncontrolled medium was $4 \mathrm{mg} / \mathrm{ml}$ and its final $\mathrm{pH}$ was 9.0 . The growth was stimulated by $\mathrm{pH}$ control with tartaric acid and, to a lesser extent, by fumaric acid and lactic acid. On the other hand, the cells from the uncontrolled culture formed $4.5 \mathrm{mg} / \mathrm{ml}$ of APc, while the cells from $\mathrm{pH}$ controlled culture formed only $1 \mathrm{mg} / \mathrm{ml}$. Products in the reaction mixture of penicillin $\mathrm{G}$ and the cells of each stage of growth at $\mathrm{pH} 7.5$ were tested on silicagel TLC. The cells of early stage of growth or $\mathrm{pH}$ controlled culture were very weak in activities of APc formation. Such cells decomposed penicillin $G$ to form penicilloic acid without 6-APA formation, while cells in a late stage of growth produced mainly 6-APA.

From these results, it follows that since the early stage of cells and $\mathrm{pH}$-controlled cells had the strong penicillinase activity, they could not form APc.

When $0.5 \%$ of sodium glutamate was added to the basal medium and its $\mathrm{pH}$ was controlled with $1 \mathrm{M}$ of tartaric acid containing $10 \%$ of sucrose, the growth was increased up to $7 \mathrm{mg}$ / $\mathrm{ml}$.

\section{Inactivation of penicillinase}

Even the cells possessing high penicillinase activity, if the enzyme was inactivated, may be used for APc production. Inactivation of penicillinase was therefore attempted. To inactivate the penicillinase from $\mathrm{pH}$-controlled cells or early stage of cells, two methods were considered: (1) incubation at $40^{\circ} \mathrm{C}$ in alkaline side and (2) the addition of some solvents to the reaction mixture for APc formation.

The first case is shown in Table II. When the broth containing the cells with potent penicillinase was incubated at $\mathrm{pH} 8.5$ for $10 \mathrm{hr}$ or $\mathrm{pH} 9.0$ for $5 \mathrm{hr}$ at $40^{\circ} \mathrm{C}$, those cells could give APc yields of $5 \mathrm{mg} / \mathrm{ml}$ and $5.3 \mathrm{mg} / \mathrm{ml}$, respectively, while untreated cells formed only
Table II. Inactivation of Penicillinase by Alkaline Treatment

\begin{tabular}{|c|c|c|c|c|c|}
\hline & & \multicolumn{4}{|c|}{$\begin{array}{l}\text { Ampicillin formed } \\
\qquad(\mu \mathrm{g} / \mathrm{nl})\end{array}$} \\
\hline & & $0^{a}$ & $5^{a !}$ & $10^{\alpha}$ & $24^{a}$ \\
\hline \multicolumn{2}{|c|}{ not treated } & 1760 & & & \\
\hline \multirow[t]{4}{*}{$\mathrm{pH}$} & 7.5 & & 2230 & 3100 & 4430 \\
\hline & 8.5 & & 4080 & 5000 & 1260 \\
\hline & 9.0 & & 5270 & 3870 & 2650 \\
\hline & 9.5 & & 4140 & 2130 & 2950 \\
\hline
\end{tabular}

a) Incubation period (hour) at $40^{\circ} \mathrm{C}$. $\mathrm{pH}$ was controlled with $28 \%$ of ammonia water.

\begin{tabular}{|l|l|}
\hline \multicolumn{1}{|c|}{ Cells } \\
not treated with alkaline \\
treated with alkaline for \\
10 hrs at $\mathrm{pH} 8.5$ \\
treated with alkaline for \\
24 hrs at $\mathrm{pH} 8.5$ \\
pH uncontrolled culture
\end{tabular}

FIG. 2. Detection of Penicillinase Activity with Silica Gel TLC.

Reaction mixture: $10 \mathrm{mg}$ of penicillin $\mathrm{G}$ and $4 \mathrm{mg}$ of cells in $1 \mathrm{ml}$ of $\mathrm{M} / 30$ phosphate buffer (pH 7.5).

After the reaction for $17 \mathrm{hr}$ at $35^{\circ} \mathrm{C}$, the supernatant of reaction mixture was spotted on silica gel TLC, and developed with the following solvent system; $n$-butylacetate- $n$-butanol-acetic acid-water (80:15:40:24).

Compounds were detected by the colored reaction with starch $-0.01 \mathrm{M}$ iodine.

\section{$1.7 \mathrm{mg} / \mathrm{ml}$ of APc.}

As seen in Fig. 2, the cells forming APc lost penicillinase but restored acylase activity, because 6-APA was formed from penicillin $G$ with slight amounts of penicilloic acid by alkaline treated cells, whereas untreated cells formed only penicilloic acid. From these 
results, it may be speculated that since acylase was more stable than penicillinase in alkaline side, it became possible to obtain the cells restoring acylase from cells of potent penicillinase by alkaline treatment.

The second method for penicillinase inactivation is seen in Table III. When xylene

\section{Table III. Inactivation of Penicillinase By SOLVENTS}

Xylene or $n$-butylacetate was added to the reaction mixture described in Methods.

Reaction was performed for $24 \mathrm{hr}$ at $35^{\circ} \mathrm{C}$.

\begin{tabular}{lrc}
\hline \multicolumn{1}{c}{ Solvent } & & $\begin{array}{c}\text { APc formed } \\
(\mu \mathrm{g} / \mathrm{ml})\end{array}$ \\
\hline not treated & & 780 \\
Xylene & $10 \%$ & 2700 \\
& $2 \%$ & 2600 \\
$n$-Butylacetate & $10 \%$ & 3600 \\
& $2 \%$ & 2100 \\
\hline
\end{tabular}

or $n$-butylacetate was added to the reaction mixture, $\mathrm{APc}$ formation was increased from $780 \mu \mathrm{g} / \mathrm{ml}$ to about $3000 \mu \mathrm{g} / \mathrm{ml}$.

In this case, it was thought that penicillinase was inhibited more strongly than acylase by these solvents. On the other hand, benzene, dioxane and phenol inactivated both penicillin acylase and penicillinase.

\section{Conditions for APc production}

In a previous paper, ${ }^{4 \prime}$ it was reported that $10.7 \mathrm{mg} / \mathrm{ml}$ of APc was formed by the intact cells of $K$. citrophila. Some conditions for more APc production were investigated.

It was already reported ${ }^{4}$ that the optimum $\mathrm{pH}$ for APc formation was 6.5 , but it was found that during the reaction, $\mathrm{pH}$ of reaction mixture was decreased slightly. So optimum $\mathrm{pH}$ was studied under the $\mathrm{pH}$ control. In this experiment, reaction mixtures contained $1 / 30 \mathrm{M}$ phosphate buffer of each $\mathrm{pH}$, to which the $\mathrm{pH}$ of the reaction mixture was controlled with diluted $\mathrm{NaOH}$ or $\mathrm{HCl}$ during the reaction.

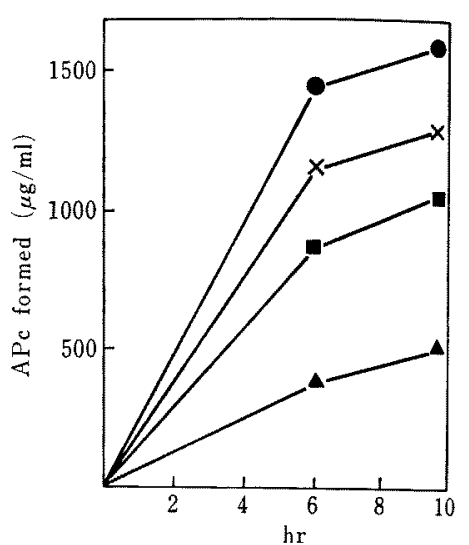

Fig. 3. Effect of $\mathrm{pH}$ Control on Ampicillin Formation.

- controlled to $\mathrm{pH} 6.5, \square-\mathrm{controlled}$ to pH 5.5, $\Delta-\Delta$ controlled to $\mathrm{pH} 4.5, \times-\times$ not controlled

Reaction mixtures were controlled to the initial $\mathrm{pH}$ with $\mathrm{N} / 10 \mathrm{HCl}$ or $\mathrm{N} / 10 \mathrm{NaOH}$.

The initial $\mathrm{pH}$ of uncontrolled reaction was pH 6.5.

TABle IV. AmPICILlin Formation from D-Phenylglycine

Reaction mixture: $10 \mathrm{mg}$ of 6-APA, $25 \mathrm{mg}$ of phenylglycine methylester $\mathrm{HCl}$ and $30 \mathrm{mg}$ of cell in $1 \mathrm{ml}$ of $\mathrm{M} / 30$ phosphate buffer $(\mathrm{pH} 6.5$ ). Incubated at $35^{\circ} \mathrm{C}$.

\begin{tabular}{llc}
\hline & \multicolumn{2}{c}{ APc formed $(\mu \mathrm{g} / \mathrm{ml})$} \\
& $2 \mathrm{hr}$ & $20 \mathrm{hr}$ \\
\hline $\begin{array}{c}\text { D-Phenylglycine } \\
\text { methylester } \mathrm{HCl}\end{array}$ & 7000 & 11000 \\
$\begin{array}{c}\text { DL-Phenylglycine } \\
\text { methylester } \mathrm{HCl}\end{array}$ & 3400 & 6100 \\
$\begin{array}{c}\text { L-Phenylglycine } \\
\text { methylester } \mathrm{HCl}\end{array}$ & trace & 2000 \\
\hline
\end{tabular}

As seen in Fig. 3, the optimum $\mathrm{pH}$ was 6.5, too. It was reported by Kaufmann group and Rolinson group ${ }^{5,6\}}$ that the optimum $\mathrm{pH}$ of acylase from $E$. coli was $4.5 \sim 5.5$. The optimum $\mathrm{pH}$ of acylase from $K$. citrophila was thus found to differ from that from $E$. coli.

Effect of D-form of phenylglycine on APC production was then tested. As shown in Table IV, $11 \mathrm{mg} / \mathrm{ml}$ of APc was formed from 
D-form and $6.1 \mathrm{mg} / \mathrm{ml}$ from DL-form, but from $\mathrm{L}$-form, only $2 \mathrm{mg} / \mathrm{ml}$ of APc was formed. It was already found that $\mathrm{D}(-$ ) ampicillin was produced from DL-phenylglycine. But which form of APc was produced from Lform of phenylglycine has yet remained to be decided.

Surface active agents were found to enhance APc production. As seen in Table $\mathrm{V}$, cation $\mathrm{PB}-40$, catiogen $\mathrm{H}$, nonione $\mathrm{E} 208$ and aerosol enhanced APc production, while vitamins, nucleotides, nucleosides, amino acids, sugars and inorgnic compounds were not effective. As seen in Table VI, DL-phenylalanine inhibited the APc formation. The inhibitory effect of phenylalanine could be ascribed to its structurally competitive effect to phenylglycine. Some inorganic compounds, $\mathrm{ZnCl}_{2}, \mathrm{HgCl}_{2}$, $\mathrm{NiCl}_{2}, \mathrm{MnSO}_{4}, \mathrm{FeSO}_{4}, \mathrm{CuSO}_{4}, \mathrm{AsO}_{3},\left(\mathrm{NH}_{4}\right)_{6}{ }^{-}$ $\mathrm{Mo}_{7} \mathrm{O}_{24}$ and $\mathrm{SnCl}_{2}$ inhibited the enzyme reaction, $100,86,82,87,82,100,82,82,92$ and $67 \%$ as inhibition per cent, when $50 \mathrm{~mm}$ of each compound was added. However, $\mathrm{NaCl}$, $\mathrm{KCl}, \mathrm{MgCl}_{2}, \mathrm{NH}_{4} \mathrm{Cl}, \mathrm{Na}_{2} \mathrm{WO}_{4}$ and $\mathrm{NaF}$ did not inhibit the enzyme reaction, when $50 \mathrm{~mm}$ of each compound was added to the reaction mixture.

When $25 \mathrm{mg}$ of D-phenylglycine methylester $\mathrm{HCl}$ and $0.5 \mu \mathrm{l}$ of catiogen $\mathrm{H}$ were added to the reaction mixture, APc productivity was increased up to $12 \mathrm{mg} / \mathrm{ml}$.

\section{Enzyme activity of the cells used repeatedly}

After the enzyme reaction to form $\mathrm{APC}$ for $4 \mathrm{hr}$, cells were separated from reaction mixture and washed with water; then, the cells were suspended again in new reaction mixture. Such a procedure was repeated five times and then APc productivity of each reaction was ixamined. As a result, APc productivity of the cells was not decreased in each reaction, lowever, the total volume of reaction mixture $n$ the next experiment was more decreased han before (Table VII), because a part of the
Table V. Effects of Surface Active Agents on AMPICILlin Formation

Surface active agents were added to the reaction mixture described in Methods.

Incubated for $20 \mathrm{hr}$ at $35^{\circ} \mathrm{C}$.

\begin{tabular}{lcc}
\multicolumn{1}{c}{ S. A. Agent } & $\begin{array}{c}\text { APc formed } \\
(\mu \mathrm{g} / \mathrm{ml})\end{array}$ \\
\hline not added & $5 \mu 1 / \mathrm{ml}^{a)}$ & 4000 \\
Cation P.B. 40 & $0.5 \mu 1 / \mathrm{ml}^{a>}$ & 6400 \\
Catiogen H & $1 \mathrm{mg} / \mathrm{ml}^{a)}$ & 6000 \\
Nonion E 208 & $1 \mathrm{mg} / \mathrm{ml}^{a)}$ & 6800 \\
Aerosol OT & \\
\hline
\end{tabular}

a) Concentration of surface active agents in the reaction mixture.

Table VI. Inhibition of Ampicillin Formation by Phenylalanine

DL-Phenylalanine was added to the reaction mixture described in Methods.

Incubated for $20 \mathrm{hr}$ at $35^{\circ} \mathrm{C}$.

\begin{tabular}{cc}
$\begin{array}{c}\text { DL-Phenylalanine added } \\
\mathrm{mg} / \mathrm{ml}\end{array}$ & $\begin{array}{c}\text { Inhibition } \\
\%\end{array}$ \\
\hline 0 & 0 \\
0.25 & 16 \\
1 & 38 \\
5 & 51 \\
10 & 60 \\
\hline
\end{tabular}

Table VII. Enzyme Activity of the Cells USED REPEATEDLY

Reaction mixture: 6-APA, $10 \mathrm{mg} / \mathrm{ml}$; DL-phenylglycine methylester $\cdot \mathrm{HCl}, 25 \mathrm{mg} / \mathrm{ml}$; Cells, $25 \mathrm{mg} /$ $\mathrm{ml}$; in $1 / 30 \mathrm{M}$-phosphate buffer.

Incubated for $4 \mathrm{hr}$ at $35^{\circ} \mathrm{C}$.

\begin{tabular}{ccc}
\hline Run & $\begin{array}{c}\text { Volume of reaction } \\
\text { mixture } \\
(\mathrm{ml})\end{array}$ & $\mathrm{APc}$ \\
$(\mu \mathrm{g} / \mathrm{ml})$ \\
\hline 1 & 200 & 3880 \\
2 & 160 & 2850 \\
3 & 120 & 3630 \\
4 & 88 & 3120 \\
5 & 75 & 3440 \\
\hline
\end{tabular}

cells were lysed in each reaction.

Preservation of the enzymatic activity

Intact cells of $K$. citrophila were preserved 
at $4^{\circ} \mathrm{C}$ or $-17^{\circ} \mathrm{C}$. It was found that the cells could maintain the acylase activity over one month in both conditions.

Acetone-dried cells were also prepared and stored for one month at room temperature. As shown in Table VIII, the acetone-dried cells were found to accumulate APc more than the intact cell.

\section{TABle VIII. ENZyme Activity of ACEtone- DRIed CelLS}

Reaction mixture: 6-APA, $10 \mathrm{mg} / \mathrm{ml}$; DL-phenylglycine methylester $\cdot \mathrm{HCl}, 25 \mathrm{mg} / \mathrm{ml}$; in $1 / 30 \mathrm{M}-$ phosphate buffer.

Incubated for $4 \mathrm{hr}$ at $35^{\circ} \mathrm{C}$.

\begin{tabular}{lcc}
\hline Cells & DCW $(\mathrm{mg} / \mathrm{ml})$ & $\mathrm{APc}(\mu \mathrm{g} / \mathrm{ml})$ \\
\hline Acetone-dried cell & 18 & 2600 \\
& 36 & 4000 \\
Intact cell & 18 & 2900 \\
& 36 & 3300 \\
\hline
\end{tabular}

Table IX. Formation of Ampicillin from Penicillin G

Reaction mixture: $10 \mathrm{mg}$ of Penicillin $\mathrm{G}, 10 \mathrm{mg}$ of phenylglycine amide- $\mathrm{HCl}$ and $20 \mathrm{mg}$ of cell in 1.0 $\mathrm{ml}$ of $1 / 30 \mathrm{M}$ phosphate buffer. Incubated at $35^{\circ} \mathrm{C}$.

\begin{tabular}{|c|c|c|c|}
\hline $\mathrm{pH}$ & $\begin{array}{c}\text { Cell } \\
\text { addition }\end{array}$ & $\begin{array}{c}\text { APc formed } \\
4 \mathrm{hr}\end{array}$ & $\begin{array}{c}(\mu \mathrm{g} / \mathrm{ml})^{a)} \\
20 \mathrm{hr}\end{array}$ \\
\hline \multirow[t]{2}{*}{3.5} & + & 3.2 & 5.8 \\
\hline & - & & 0.5 \\
\hline \multirow[t]{2}{*}{4.5} & + & 3.2 & 6.8 \\
\hline & - & & 0.6 \\
\hline \multirow[t]{2}{*}{5.5} & + & 3.8 & 6.9 \\
\hline & - & & 0.8 \\
\hline \multirow[t]{2}{*}{6.5} & + & 2.6 & 4.8 \\
\hline & - & & 0.1 \\
\hline \multirow[t]{2}{*}{7.5} & + & 4.6 & 9.0 \\
\hline & - & & 1.7 \\
\hline
\end{tabular}

a) Bioassay with Staph, aurets $209 \mathrm{P}$

Formation of ampicillin from penicillin $G$

In this experiment, penicillin $\mathrm{G}$ was added to the reaction mixture in place of 6-APA. After the reaction, penicillin $G$ was removed with the extraction of ethylacetate and the reaction mixture was assayed by the clinder method using St. aureus 209p. As seen in Table IX, as highest yield, $9.0 \mu \mathrm{g} / \mathrm{ml}$ of active material as APc was obtained from $20 \mathrm{mg} / \mathrm{ml}$ of Penicillin $\mathrm{G}$ at $\mathrm{pH} 7.5$ and this material was identified as APc on silicagel TLC by use of the following three solvent systems: (1) $n$-butylacetate- $n$-butanol-acetic acid-water (80: 15:40:24), (2) $n$-butanol-ethylether-acetonewater (28:9:9:5) and (3) isoamylacetatemethanol-formic acid-water $(65: 20: 5: 10)$. The $R f$ values were $0.40,0.42$ and 0.20 in (1), (2) and (3) solvents, respectively. These $R f$ values were in good accord with those of $\mathrm{APc}$, so that it is clear that APc was formed from penicillin $G$, though its more definite identification was not performed.

Acknowledgement. The authors are very grateful to Mrs. Y. Sato and Miss S. Tanaka for their skilful technical asistance.

\section{REFERENCES}

1) T. Nara, M. Misawa, R. Okachi and M. Yamamoto, Agr. Biol. Chem., 35, 1676 (1971).

2) R. Okachi, M. Misawa and T. Nara, ibid., 36, 925 (1972).

3) T. NARA, R. Okachi and M. Misawa, J. Antibiotics, 24, 321 (1971).

4) R. Okachi, M. Misawa, T. Deguchi and T. Nara, Agr. Biol. Chem., 36, 1193 (1972).

5) W. Kaufmann, K. Bauer and H. A. Offe, Antimicrob. Agent Ann., 1960, p. 1, N.Y.

6) G. N. Rolinson, F. R. Batchelor, D. Butterworth, J. Cameron-Wood, M. Cole, G. C. Eustace, M. V. Hart, M. Richards and E. B. Chain, Nature, 187, 236 (1960). 